\title{
Multivariate analysis of the dominant and sub-dominant epipelic diatoms and water quality data from South African rivers
}

\author{
F García-Rodríguez ${ }^{1}$, GC Bate ${ }^{1 *}$, P Smailes ${ }^{1}$, JB Adams ${ }^{1}$ and D Metzeltin ${ }^{2}$ \\ ${ }^{1}$ Nelson Mandela Metropolitan University, Botany Department, PO Box 77000, Port Elizabeth 6031, South Africa \\ ${ }^{2}$ Botanisches Institut der Universität Frankfurt, Siesmayerstr. 77, Frankfurt, D-60323, Frankfurt (Main), Germany
}

\begin{abstract}
Data are presented on the distribution of the dominant and sub-dominant epipelic diatoms found in South African rivers from different regions of the country. A multivariate analysis identified 36 diatom species that were associated with different levels of TDS, $\mathrm{PO}_{4}, \mathrm{NH}_{4}$ and $\mathrm{SiO}_{2}$. Three groups of rivers were identified. Group I consisted of sites with high $\mathrm{PO}_{4}$ and $\mathrm{SiO}_{2}$, which corresponded to Durban Metropolitan Area sites, Kruger National Park rivers, the rivers in the Johannesburg Metropolitan Area and the Orange River. In these rivers 12 diatom species were identified that might indicate those water quality characteristics. Group II included stations where the water quality had high TDS and $\mathrm{NH}_{4}$ values which were associated with most stations in the Swartkops River in the Eastern Cape. The indicators in this group comprised 12 diatom species. Group III were from sampling stations where the water had low levels of minerals, i.e. the upper reaches of the Gamtoos River and the Swartkops River in the Eastern Cape, the Olifants River in the Northern Cape, rivers sampled in KwaZulu-Natal and the Northern Cape. At these sites, 13 diatom species were found as dominants in this better water quality. Water quality data collected during this study showed that over $50 \%$ of the river systems display some degree of eutrophication and thus efforts should be made to reduce inputs of nutrients and pollutants to those rivers.
\end{abstract}

Keywords: ammonium, diatoms, phosphate, rivers, South Africa, total dissolved solids

\section{Introduction}

Freshwater is a limited resource. According to the World Meteorological Organization and the United Nations Environment Programme, 20 to $40 \%$ of the South African available freshwater is withdrawn from the river in which it occurs. However, by 2025 , this percentage is expected to increase to over $40 \%$, mainly because of agricultural, domestic and industrial activities. Therefore, as freshwater stress is likely to increase, knowledge of the water quality will be important. This means that both chemical and biological data will be very necessary to South African authorities to correctly manage and exploit the freshwater resources. In this sense, chemical data can be used to determine the degree of contamination or the trophic status of the rivers. Biological data, such as diatom data, can provide further and complementary information on biodiversity, which is most important in order to understand the structure and functioning of the systems. Thus, knowledge of diatom distribution in South African rivers could be used to infer water quality. This is possible because diatoms are distributed along an environmental gradient in such a way that they display optima and tolerances (Weckström, 2006; Dixit et al., 2002; Rosén et al., 2000). Hence, if samples are taken over a wide geographical area that covers various environmental conditions, it will be possible to determine the optima and tolerances for different diatom species, from which water quality could be determined. In this sense, Taylor et al. (2005), De la Rey et al. (2004) and Harding et al. (2004) have developed some diatom indices to determine water quality. However, they have also pointed out the necessity of

* To whom all correspondence should be addressed.

前 +2733 330 5252; fax: +2733 330 5252;

e-mail: bateg@netfocus.co.za

Received 21 July 2006; accepted in revised form 19 July 2007. gathering diatom samples from a wide geographical range.

This paper is an extension of previous research on the water quality of South African rivers (Bate et al., 2004a; b), which focused on the determination of the classes of water quality using environmental data and samples covering a wide range of phytogeographic regions in South Africa. They proposed 5 classes of water quality using 15 water quality variables (Table 1). However, they did not identify diatom species as indicators of such water quality classes. In this paper, the data used by Bate et al. (2004a, b) are re-visited and a multivariate analy-

\begin{tabular}{|c|c|c|c|c|c|}
\hline \multicolumn{6}{|c|}{$\begin{array}{c}\text { TABLE } 1 \\
\text { Median values }\left(\mathrm{mg} \cdot \ell^{-1}\right) \text { used in the construction } \\
\text { of the Swartkops River water quality classes } \\
\text { (after Bate et al., 2004b) }\end{array}$} \\
\hline & \multicolumn{4}{|c|}{ Swartkops River water classes } & \multirow[b]{2}{*}{ Class 5} \\
\hline & Class 1 & Class 2 & Class 3 & Class 4 & \\
\hline $\mathrm{Ca}^{++}$ & 3.00 & 24.25 & 45.50 & 59.14 & 88.00 \\
\hline $\mathrm{Cl}^{-}$ & 45.00 & 428.00 & 811.00 & 1038.75 & 1577.00 \\
\hline $\mathrm{EC}$ & 17.30 & 215.73 & 414.15 & 509.31 & 811.00 \\
\hline$\overline{\mathrm{F}^{-}}$ & 0.00 & 0.10 & 0.20 & 0.30 & 0.40 \\
\hline $\mathrm{K}^{+}$ & 0.70 & 9.08 & 17.45 & 23.00 & 34.20 \\
\hline $\mathrm{Mg}^{++}$ & 4.00 & 35.25 & 66.50 & 84.73 & 129.00 \\
\hline $\mathrm{Na}^{+}$ & 28.00 & 245.75 & 463.50 & 603.82 & 899.00 \\
\hline $\mathrm{NH}_{4}^{+}$ & 0.00 & 0.47 & 0.93 & 1.00 & 1.86 \\
\hline $\mathrm{NO}_{3}^{-}$ & 0.00 & 0.75 & 1.49 & 1.69 & 2.98 \\
\hline $\mathrm{pH}$ & 6.81 & 7.33 & 7.84 & 8.15 & 8.87 \\
\hline $\mathrm{PO}_{4}^{--}$ & 0.01 & 1.75 & 3.49 & 4.26 & 6.97 \\
\hline $\mathrm{SiO}_{2}$ & 1.20 & 2.35 & 3.50 & 4.33 & 5.80 \\
\hline $\mathrm{SO}_{4}^{--}$ & 0.00 & 128.50 & 257.00 & 315.02 & 514.00 \\
\hline Alkalinity & 11.00 & 82.00 & 153.00 & 203.02 & 295.00 \\
\hline TDS & 103.00 & 922.25 & \begin{tabular}{|l|}
1741.50 \\
\end{tabular} & 2264.98 & 3380.00 \\
\hline
\end{tabular}


sis using both water quality data and diatom abundance values is undertaken. The purpose of this paper is to identify epipelic diatom species as indicators of water chemistry conditions (i.e., TDS, $\mathrm{NH}_{4}, \mathrm{SiO}_{2}, \mathrm{PO}_{4}$ ), from a number of South African rivers located in different phytogeographic regions of the country.

\section{Materials and methods}

\section{The study area}

As far as possible, water samples were colleted at Department of Water Affairs and Forestry (DWAF) river water quality monitoring sites (115), but some were collected at Rand Water (7), Umgeni Water (13) and Durban Metro sites (5) and analysed in their laboratories. Samples were collected in the Western Cape (14), Free State (6), Northern Cape (18), KwaZulu-Natal rural (8), Pietermaritzburg (13) Northern Province (8), Eastern Cape (18), Kruger National Park (11), Durban Metropolitan area (5), Rand Water Board sites in Gauteng (7) and Gauteng Johannesburg/Pretoria area. Full details of the sampling sites, GPS co-ordinates and date of sampling are provided in Bate et al. (2004a). The rivers are located in different phytogeographical regions with different climatic conditions and degree of human influence. The Swartkops River was most intensively sampled because of the geographical proximity to the Nelson Mandela Metropolitan University (Van der Molen, 2000).

\section{Diatom collection and processing}

Epipelon samples were taken using a length of glass tube $(5 \mathrm{~mm}$ ID) that was drawn across the sediment and allowed to fill by hydrostatic pressure with a mixture of surface sediment and water. This was repeated up to 5 times in different positions in shallow portions of the river where the water was flowing in order to get a sample that included any possible micro-habitats. Each time a sample was taken using this method, the tube was drawn across the sediment ( $\sim 0.25$ to $1 \mathrm{~m}$ in length depending on the availability of sediment). Riffles and rapids were avoided unless there was a section where the sediment could be clearly observed. DWAF staff sample at sites where there is a water flow-gauge, hence all samples were collected below the gauging weir. The sediment/water mixture was stored in a plastic sample container $(50 \mathrm{~m} \ell)$.

In a field laboratory on the same day the sample was placed in a Petri dish ( $\sim 1$ to $2 \mathrm{~mm}$ deep). The sediment was allowed to settle overnight. The following morning most of the supernatant was drawn off and 5 clean degreased cover slips (covering $47 \%$ of the sediment surface) were placed on top of the wet sediment. On the same day (ca. $2 \mathrm{~h}$ later after incubation in diffuse light) in accordance with the findings of Minne (2003), the cover slips were carefully removed with as little sediment as possible. In this way only living epipelic cells that had attached to the cover slips were sampled. The 5 cover slips from each sample were placed in glass bottles, air-dried and transported to the laboratory. There is no time limit at this stage to process the diatoms further. To each glass bottle containing the cover slips, $2 \mathrm{~m} \ell$ of $\mathrm{KMnO}_{4}$ (saturated) and $2 \mathrm{~m} \ell$ of $\mathrm{HCl}(10 \mathrm{M})$ was added. This mixture was heated on a hot-plate at ca. $60^{\circ} \mathrm{C}$ until the solution cleared (ca. 20 to $40 \mathrm{~min}$ ) and became straw-coloured. Permanent slides were mounted in Naphrax ${ }^{\circledR}$. A minimum of 200 valves were counted and identified in each slide at $1000 \mathrm{x}$ magnification. Diatoms were identified according to Cholnoky (1953; 1958; 1960; 1968; 1970), Archibald (1983), Lange-Bertalot (2001), Metzeltin and Lange-Bertalot (2003) and Metzeltin et al. (2005).

\section{Water quality}

The water samples $(250 \mathrm{~m} \ell)$ collected at each river site were taken by the DWAF or Water Board representative present during the collection, preserved with $\mathrm{HgCl}_{2}\left(8 \mathrm{mg} \cdot \ell^{-1}\right)$ and analyzed, in the case of the DWAF sites, at the laboratories of Resource Quality Services (RQS), DWAF, Pretoria, South Africa (National Laboratory Accreditation Service, Accredited Laboratory No. T0073). The samples were analysed for $\mathrm{EC}, \mathrm{NH}_{4}, \mathrm{NO}_{2}+\mathrm{NO}_{3}$, $\mathrm{F}, \mathrm{pH}$, alkalinity as $\mathrm{CaCO}_{3}, \mathrm{Na}, \mathrm{Mg}, \mathrm{Si}, \mathrm{PO}_{4}, \mathrm{SO}_{4}, \mathrm{Cl}, \mathrm{K}, \mathrm{Ca}$ and total dissolved solids (TDS). Dissolved oxygen (WTW, Oxi 330), electrical conductivity (YSI model 30 conductivity meter), $\mathrm{pH}$ (UniFet $100 \mathrm{pH}$ meter) and temperature (read from the conductivity meter) were measured in situ at some sites. In those cases where the samples had been taken by Rand Water, Durban Metro or Umgeni Water, the water samples were handled and analysed in their own prescribed manner.

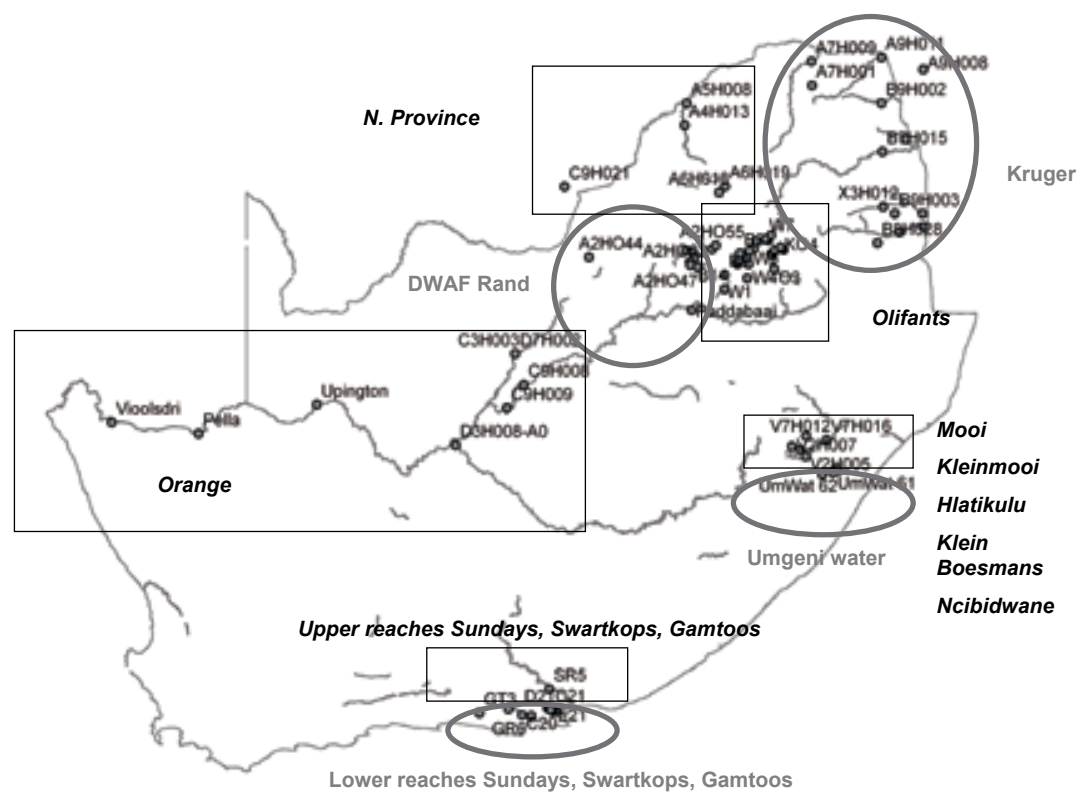

Figure 1

Selected sampling stations in South Africa. Stations located in the rectangles and labelled with italics indicate good water quality (i.e. low nutrients, TDS and $\mathrm{SiO}_{2}$ ). Stations located in the ellipses and labelled with grey indicate high levels of nutrients, TDS and $\mathrm{SiO}_{2}$. For geographical coordinates and codes of the sampling stations, see Bate et al. (2004a, Section 3). 


\section{Statistics}

Canonical Correspondence Analysis (CCA) was performed for water quality and diatom data from 148 sampling stations (Fig. 1) using CANOCO for Windows Version 4.5 (Ter Braak and Šmilauer 1998). First an exploratory analysis was run using all water quality variables. A subset of these variables was selected by examination of the variance inflation factor (VIF). Those variables that exhibited a VIF $>10$ (i.e. multiple co-linear variables), were removed one at a time (Wilson et al., 1994). After each elimination, CCA was re-run and the VIFs were reexamined until no extreme values were observed. At the end of this analysis, $\mathrm{PO}_{4}, \mathrm{SiO}_{2}$, TDS and $\mathrm{NH}_{4}$ (i.e. VIF $<10$ ), were selected. Abundance values were calculated and plotted in the ordination diagram for the 95 dominant diatom species using CANODRAW, which is available in CANOCO for Windows. Thus a species-by-species gradient analysis was used to establish different diatoms as indicators of water quality conditions in South African rivers. Those species that showed clear maximum values (i.e. higher than or equal to $30 \%$ ) along the water quality gradient were selected as indicators of different trophic conditions (in terms of $\mathrm{PO}_{4}, \mathrm{SiO}_{2}$, TDS and $\mathrm{NH}_{4}$ ). The significance of the ordination diagram was assessed with the Monte Carlo permutation test using 1000 unrestricted permutations.

\section{Results}

The distribution of water quality data for all sampling stations presented here has been published elsewhere (Bate et al., 2004a; b). In this paper, the focus is on the multivariate relationship between diatoms and water quality variables.

Figure 2 shows the distribution of water quality variables within the CCA ordination diagram and Fig. 3 shows the ordination diagram (water quality variables and sites) for all 148 sampling stations. The Monte Carlo test indicated that the ordination diagram was significant $(\mathrm{F}=1.56, \mathrm{p}<0.05)$, and the relationship species-water quality data of the first two ordination axes (axis $1 \lambda=0.72$; axis $2 \lambda=38$ ) explained $69.8 \%$ of the variance.

According to these data, 3 main groups were identified. Group I contained those sites with high $\mathrm{PO}_{4}$ and $\mathrm{SiO}_{2}$ which corresponded to the Umgeni Water sites in the Pietermaritzburg area, Kruger National Park, Gauteng and the Orange River sites. Group II consisted of sampling stations with high TDS and $\mathrm{NH}_{4}$ values and grouped most stations of the Swartkops River in the Eastern Cape. In Group III all those stations with low levels of water quality variables were observed (i.e. upper reaches of the Gamtoos River, Swartkops River, Olifants, KwaZulu-Natal sites and Northern Cape sites).

Figure 4 shows those diatom species that exhibited high abundance values in Group I (Fig. 3). The larger the bubble, the higher the abundance value. The 12 species in the upper-left quadrant of the ordination diagram accounted for a relative abundance of $\sim 30 \%$ (optimum), but also exhibited very low values in other quadrants of the ordination diagram (tolerances). Similarly, those species depicted in Fig. 5, showed relatively high
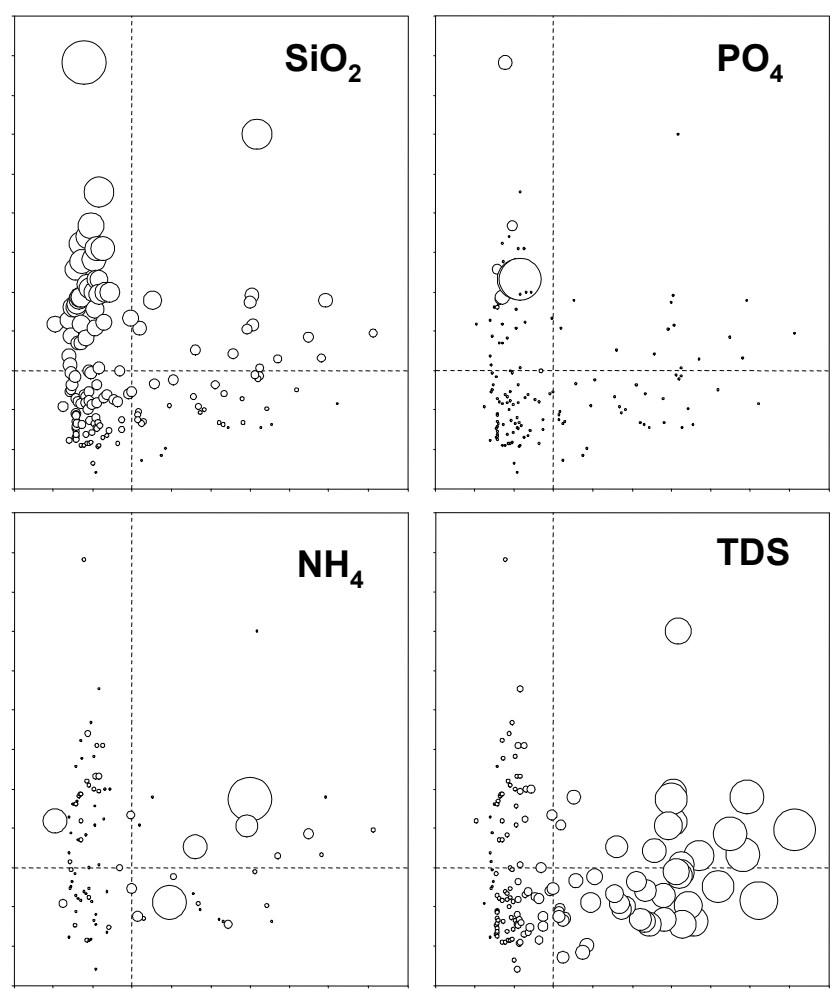

Figure 2

Value of the 4 selected water quality variables within the ordination diagram. The larger the size of the bubble, the higher the water quality variable of the sampling station. Detailed information on the water quality data has been published elsewhere (Bate et al., 2004a; b).

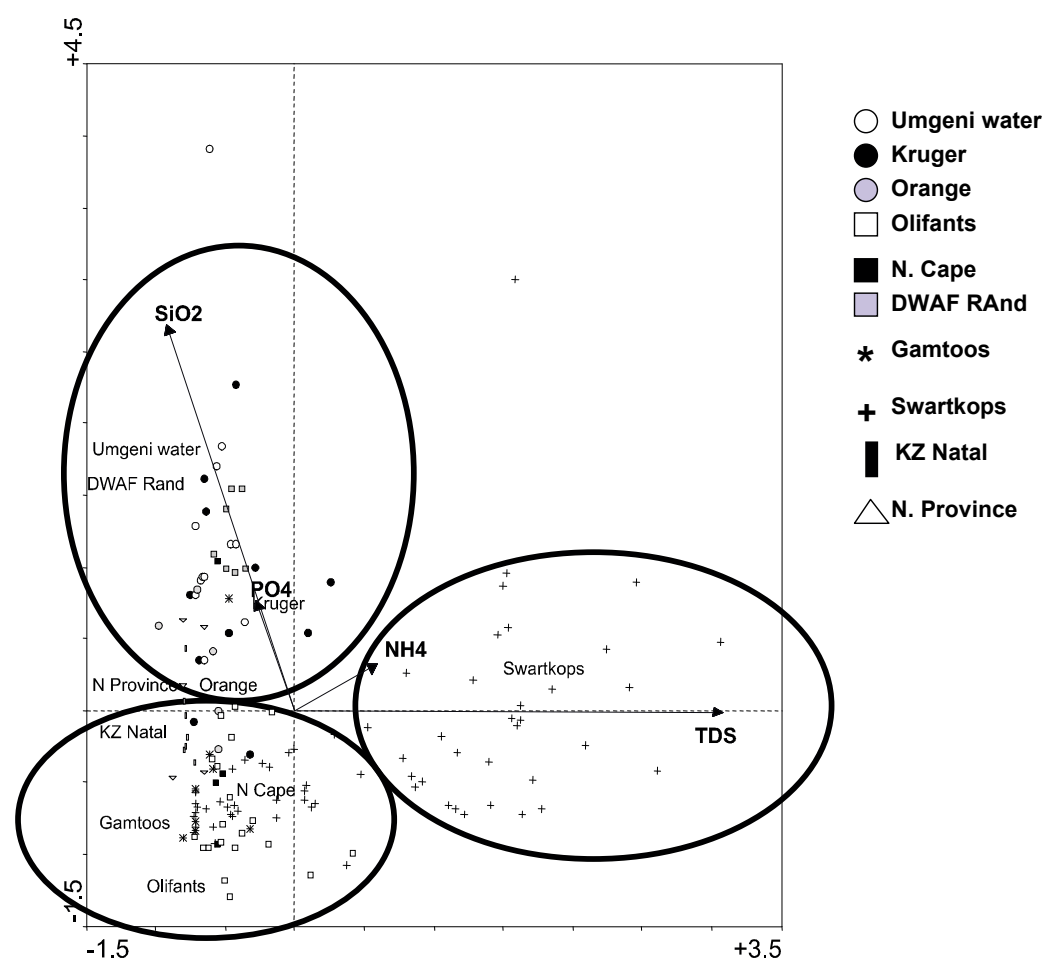

Figure 3

CCA biplot for water quality variables and sampling stations 


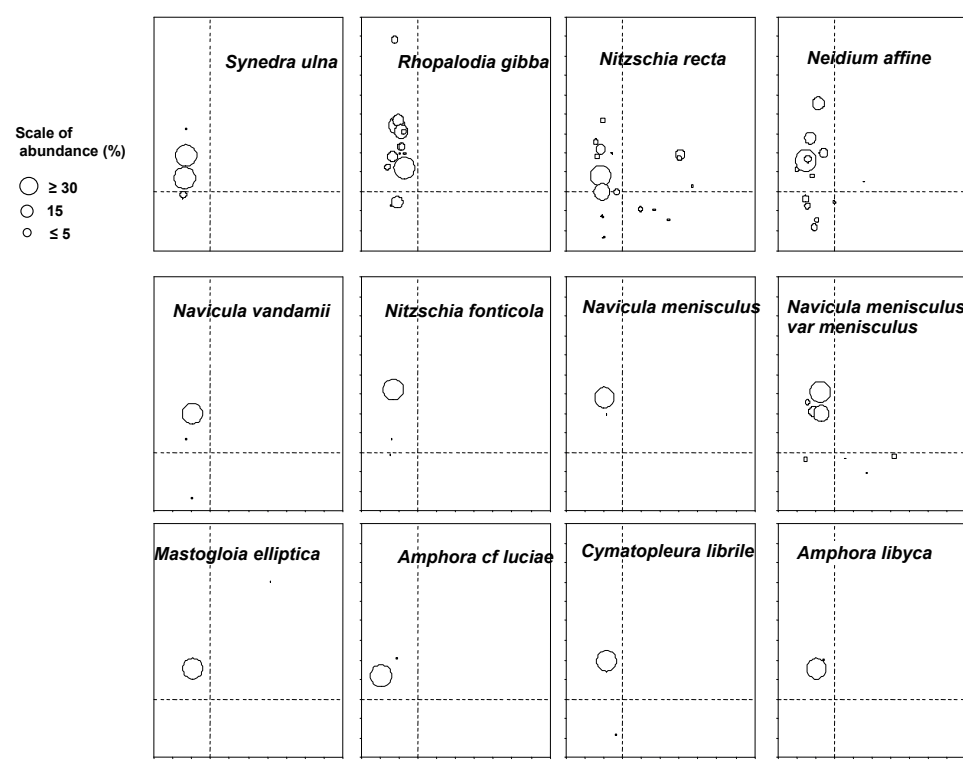

Figure 4

Relative abundance values of selected diatom species within the ordination diagram. Compare with position of the stations and direction/ longitude of the solid lines (water quality variables) of Fig. 3, and the value of the environmental variables presented in Fig. 2.

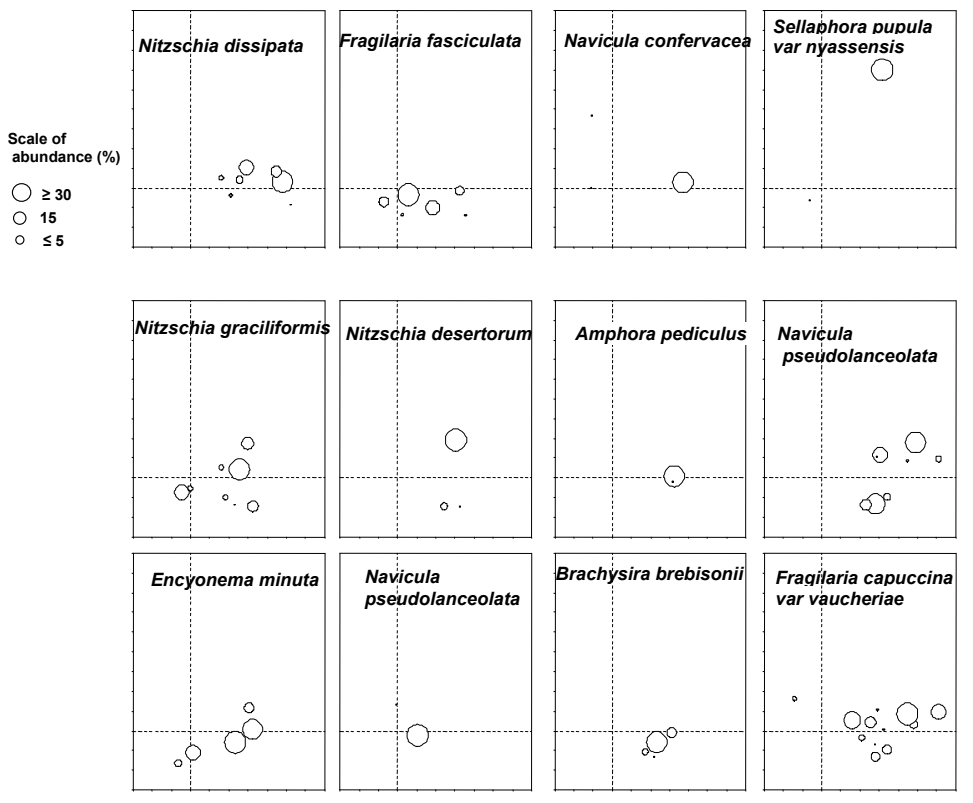

Figure 5

Relative abundance values of selected diatom species within the ordination diagram. Compare with position of the stations and direction/ length of the solid lines (water quality variables) of Fig. 3, and the value of the water quality variables presented in Fig. 2.

abundance values in the top/bottom-left quadrant with very low abundance values in other sections of the ordination diagram. Finally, in the bottom left quadrant (Fig. 6) diatom species with high abundance values are depicted.

\section{Discussion}

The three ordination groups identified for the South African rivers sampled indicate that different sampling stations displayed different limnological conditions in terms of $\mathrm{NH}_{4}, \mathrm{TDS}, \mathrm{PO}_{4}$ and
$\mathrm{SiO}_{2}$. Group I was characterised by high phosphorus and silica compounds which means a considerable degree of eutrophication. Therefore, Pietermaritzburg, Kruger National Park, Johannesburg/Pretoria and the Orange River should produce high values of primary productivity as commonly observed in eutrophic systems. Those diatoms observed in this section of the ordination diagram (Fig. 4) can certainly be considered indicators of high phosphorus and silica compounds in the water column. For example, Rhopalodia gibba (Ehrenberg) O. Müller has been observed in the Groenvlei Lake, which is considered to be eutrophic (Martin, 1960). Similarly, Synedra ulna, Mastogloia elliptica and Amphora copulata (Kützing) Schoeman et Archibald have been observed in eutrophic lakes (for example Lake Blanca in SE Uruguay, García-Rodríguez et al., 2004), and other eutrophic systems of Uruguay (Metzeltin et al., 2005). Lange-Bertalot (2001) pointed out that Navicula menisculus Schumann and Navicula vandamii Schoeman are indicators of meso to eutrophic conditions. Prygiel and Coste (2000) observed that Nitzschia recta Hantzsch and Nitzschia fonticola Grumow displayed very high relative abundances in meso to eutrophic systems. Therefore, the presence of species in Group I is in close agreement with other geographical areas and could be reliable indicators of high trophic conditions (especially high $\mathrm{PO}_{4}$ and $\mathrm{SiO}_{2}$ ).

Group II displayed high TDS values (i.e. up to $2000 \mathrm{mg} \cdot \ell^{-1}$, Van der Molen (2000)) and corresponds to those stations located in the lower reaches of the Swartkops River. Detailed information on the limnological conditions of the Swartkops River has been published elsewhere (Bate et al., 2004b). Briefly, the high TDS values of the lower Swartkops River in the Eastern Cape are a consequence of anthropogenic sources, i.e. downstream from the industrial town of Uitenhage, in which human activities include agriculture, a wool-processing factory, 3 sewage treatment works, runoff from informal settlements and discharges from light industries (e.g. leather tanning). Therefore, in the South African context, the dominant diatoms in this section of the ordination diagram (Fig. 5) could be used as indicators of impacted systems that exhibit low Secchi disk values. This is supported by Prygiel and Coste (2000) who observed that Amphora pediculus, Fragilaria capuccina, Fragilaria fasciculata, Nitzschia graciliformis, Nitzschia dissipata and Sellaphora pupula showed high abundance values in eutrophic waters defined as 'mediocre water quality'.

Group III represents the highest quality waters (i.e. low values of TDS, $\mathrm{PO}_{4}, \mathrm{NH}_{4}$ and $\mathrm{SiO}_{2}$ ), that correspond to upper reaches of the Gamtoos, Swartkops, Olifants, inland KwaZulu-Natal sites and N. Cape river sites. The most abundant diatoms in this section of the ordination diagram (Fig. 5) indicate the lowest levels of nutrients with highest Secchi disk values. Lange-Bertalot (2001) defined Navicula heimansii as an indicator of oligotrophic systems, Prygiel and Coste (2000) observed Cocconeis placentula, Gomphonema parvulum, Nitzschia linearis and Navicula gregaria in systems with a good water quality (i.e. oligo- to mesotrophic). Van Dam et al. (1994) considered $N$. 
gregaria to be eutraphenic; however, in this study the species was found in sites with a wide range of mineral concentrations (Table 2). In a similar study on diatom species in estuaries, $N$. gregaria was also widely distributed (Bate et al. 2004a). Metzeltin et al. (2005) observed Diploneis puella and Nitzschia linearis in a number of small pristine nameless creeks of Uruguay. Therefore the diatoms observed in this group could also reliably be used as indicators of good water quality in South African rivers.

The multivariate analysis on diatom and water quality data indicates that a set of 36 out of 96 dominant diatom species identified by Bate et al. (2004a) could be used as indicators of different trophic conditions of South African rivers. A further effort should be undertaken to calibrate these species in order to quantitatively use them in future water quality studies, but also to provide a basis for more detailed palaeo-ecological reconstructions of South African aquatic systems. In this sense, South Africa has a considerable tradition of diatom research (e.g.; Cholnoky, Giffen, Schoeman, Archibald) but the information is fragmentary as it is spread out in different institutions of the country. This information should be compiled and statistically harmonised to provide a large geographical database on the relationship between diatoms and water quality. This will allow managers to have access to reliable information upon which decisions can be made. For example, as a preliminary effort, the chemical data presented in Fig. 4 were used to classify the South African rivers according to water quality (Fig. 1). Sampling stations that are located in the rectangles and labelled with italics indicate a fairly good water quality (i.e. low levels of TDS, $\mathrm{PO}_{4}, \mathrm{NH}_{4}$ and $\mathrm{SiO}_{2}$ ), while those samples located within the ellipses and labelled in grey indicate some degree of water quality degradation (i.e. high levels of TDS, $\mathrm{PO}_{4}, \mathrm{NH}_{4}$ and $\mathrm{SiO}_{2}$ ). About $50 \%$ of the stations showed signs of eutrophication, which means that special attention should be paid to the management of South African rivers in order to implement measures to reduce nitrogen and phosphorus inputs. In the case of the lower reaches of the Swartkops River, the human activities prevailing in the town of Uitenhage indicate that clean-up measures are required because the water quality has been severely degraded and the international environmental legislation requirements (i.e. ISO standards) should be implemented in both the municipal and industrial sectors.

The multivariate analysis of diatom distribution in South African rivers has been shown to be a very practical tool to identify diatom species as indicators of different trophic status, but the analysis presented here should be improved and more sampling stations should be selected in the country and water samples should also be analysed. This will assist in identifying

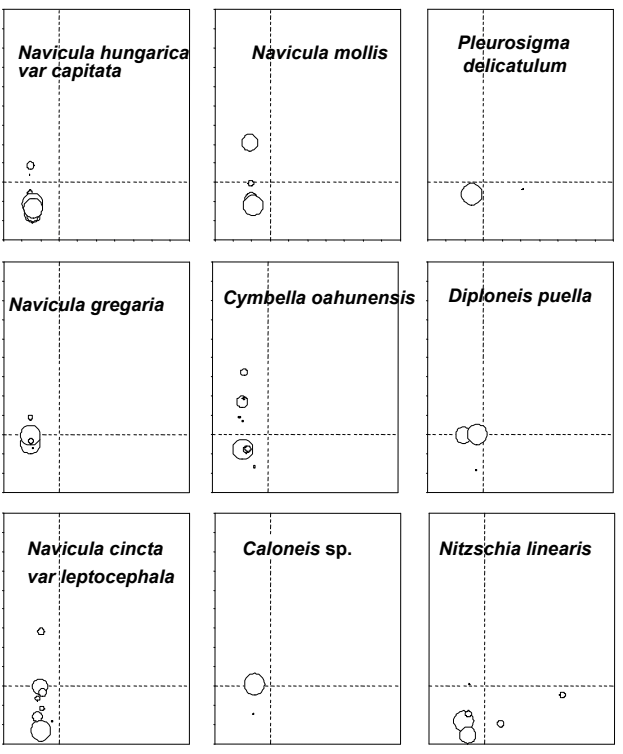

Figure 6

Relative abundance values of selected diatom species within the ordination diagram. Compare with position of the stations and direction/length of the solid lines (water quality variables) of Fig. 3 , and the value of the water quality variables presented in Fig. 2.

TABLE 2

The water quality components (mg $\ell^{-1}$, except for $\mathrm{pH}$ and $\mathrm{EC}$ ) in which Navicula gregaria (NAVIGREG) was found as the dominant species from all the sites sampled. The data compare the minimum and maximum concentrations in which the species was found by comparison with the minimum and maximum values for all the rivers from where samples were taken. The maximum and minimum percentiles are shown for each mineral element.

\begin{tabular}{|l|c|c|c|c|c|c|}
\hline & \multicolumn{2}{|c|}{ NAVIGREG data } & \multicolumn{2}{c|}{ All rivers data } & \%ile & \%ile \\
\hline Component & Min. & Max. & Min. & Max. & Min. & Max. \\
\hline $\mathrm{Ca}$ & 3.00 & 62 & 1 & 504 & 3 & 88 \\
\hline $\mathrm{Cl}$ & 15.10 & 698 & 0 & 6844 & 13 & 80 \\
\hline $\mathrm{EC}$ & 14.60 & 299 & 4.01 & 1979 & - & - \\
\hline $\mathrm{F}$ & 0.00 & 0.3 & 0 & 119 & 0 & 68 \\
\hline $\mathrm{K}$ & 0.70 & 190.4 & 0.15 & 242.6 & 5 & 99 \\
\hline $\mathrm{Mg}$ & 4.00 & 63 & 1 & 690 & 8 & 83 \\
\hline $\mathrm{Na}$ & 10.17 & 471 & 3.171 & 3645 & 12 & 85 \\
\hline $\mathrm{NH}_{4}$ & 0.00 & 0.7 & 0 & 295 & 0 & 95 \\
\hline $\mathrm{NO}_{3}$ & 0.00 & 1.32 & 0 & 340.16 & 0 & 80 \\
\hline $\mathrm{pH}$ & 6.60 & 8.99 & 4.2 & 9.57 & 5 & 97 \\
\hline $\mathrm{PO}_{4}$ & 0.01 & 96.1 & 0.002 & 336 & 7 & 98 \\
\hline $\mathrm{SiO}_{2}$ & 0.50 & 7.2 & 0.5 & 47 & 1 & 85 \\
\hline $\mathrm{SO}_{4}$ & 5.00 & 127 & 2.06 & 2114 & 2 & 72 \\
\hline $\mathrm{Alk}$ & 16.00 & 530 & 6 & 851 & 5 & 99 \\
\hline $\mathrm{TDS}$ & 92.18 & 2258 & 34 & 14139 & 1 & 90 \\
\hline
\end{tabular}

planktonic diatoms as indicators of water quality, the development of comprehensive diatom training sets for both water quality assessments and palaeo-ecological reconstructions.

\section{Acknowledgements}

The study presented here was funded by the National Research Foundation (NRF) and the Nelson Mandela Metropolitan University, using data acquired with Water Research Commission funds. 


\section{References}

ARCHIBALD REM (1983) The Diatoms of the Sundays and Great Fish Rivers in the Eastern Cape Province of South Africa. Cramer, Vaduz. 431 pp.

BATE GC, ADAMS JB and SMAILES PA (2004a) Benthic Diatoms in the Rivers and Estuaries of South Africa. WRC Report No. 1107. Water Research Commission, Pretoria, South Africa.

BATE GC, SMAILES PA and ADAMS JB (2004b) A water quality index for use with diatoms in the assessment of rivers. Water $S A 30$ (4) 493-498. http://www.wrc.org.za/archives/watersa\%20archive/2004/ Oct-04/7.pdf

CHOLNOKY BJ (1953) Diatomeenassoziationen aus dem Hennopsrivier bei Pretoria. Verh. Zool.-Bot. Ges. in Wien. 93 135-149.

CHOLNOKY BJ (1958) Die Diatomeenassoziation des Sumpfes Olifantsvlei südwestlich Johannesburg. Ber. Dtsch. Bot. Ges. 71 177-187.

CHOLNOKY BJ (1960) Beiträge zur Kentniss der Ökologie der Diatomeen in dem Swartkops-Bache nahe Port Elizabeth (Südost- Kapland). Hydrobiol. 16 229-287.

CHOLNOKY BJ (1968) Die Ökologie der Diatomeen in Binnengewässern. J. Cramer, Weinheim. 699 pp.

CHOLNOKY BJ (1970) Bacillariophyceae from the Bangweulu Swamps. Cercle Hydrobiologique de Bruxelles, Brussels.

DE LA REY PA, TAYLOR JC, LAAS A, VAN RENSBURG L and VOSLOO A (2004) Determining the possible application value of diatoms as indicators of general water quality: A comparison with SASS 5. Water SA 30 (3) 325-332. http://www.wrc.org.za/archives/ watersa $\% 20$ archive/2004/July-04/5.pdf

DIXIT SS, DIXIT AS and SMOL JP (2002) Diatom and chrysophyte transfer functions and inferences of post-industrial acidification and recent recovery trends in Killarney lakes (Ontario, Canada). J. Paleolimnol. 27 79-96.

GARCÍA-RODRÍGUEZ F, SPRECHMANN P, METZELTIN D, SCAFATI L, MELENDI DL, VOLKHEIMER W, MAZZEO N, HILLER A, VON TÜMPLING JR W and SCASSO F (2004) Holocene trophic state changes in relation to sea level variation in Lake Blanca, SE Uruguay. J. Paleolimnol. 31 99-115.

HARDING WR, ARCHIBALD CGM and TAYLOR JC (2004) The relevance of diatoms for water quality assessment in South Africa: A position paper. Water $S A 31$ (1) 41-46. http://www.wrc.org.za/downloads/watersa/2005/Jan-05/1769.pdf

LANGE-BERTALOT H (2001) Navicula sensu stricto, 10 genera separated from Navicula sensu lato Frustulia. In: H Lange-Bertalot (ed.)
Diatoms of Europe (Vol. 2) ARG Gantner Verlag, Ruggell. 526 pp. MARTIN ARH (1960) The ecology of Groenvlei, a South African Fen: Part 1. The preliminary communities. J. Ecol. 48 55-71.

METZELTIN D and LANGE-BERTALOT H (2003) Diatoms from the 'island continent' Madagascar. In: H Lange-Bertalot (ed.) Iconographia Diatomologica (Vol. 11) ARG Gantner Verlag, Rugell. 286 pp.

METZELTIN D, LANGE-BERTALOT H and GARCIA-RODRIGUEZ F (2005) Diatoms of Uruguay. In: H Lange-Bertalot (ed.) Iconographia Diatomologica (Vol. 15). ARG Gantner Verlag. Distributed by Koeltz Scientific Books. Königstein. 737 pp.

MINNE C (2003) Diatoms as Indicators of Water Quality in Estuaries. Unpublished M.Sc. thesis, University of Port Elizabeth (now Nelson Mandela Metropolitan University). $161 \mathrm{pp}$.

PRYGIEL J and COSTE M (2000) Guide méthodologique pour la mise en æuvre de l'Indice Biologique Diatomées. NF T 90-354. Agences de l'Eau - Cemagref, Bordeaux. 134 pp.

ROSÉN P, ROLAND HALL R, KORSMAN T and RENBERG I (2000) Diatom transfer-functions for quantifying past air temperature, $\mathrm{pH}$ and total organic carbon concentration from lakes in northern Sweden. J. Paleolimnol. 24 109-123.

TAYLOR JC, HARDING WR, ARCHIBALD CGM and VAN RENSBURG 1 (2005) Diatoms as indicators of water quality in the Jukskei-Crocodile river system in 1956 and 1957, a re-analysis of diatom count data generated by BJ Cholnoky. Water SA 31 (2) 1-10. http://www.wrc.org.za/downloads/watersa/2005/Apr-05/1757.pdf

TER BRAAK CFJ and ŠMILAUER P (1998) CANOCO Reference Manual and User's Guide to CANOCO for Windows: Software for Canonical Community Ordination (Version 4). Microcomputer Power (Ithaca, NY, USA), 352 pp. + Appendix.

VAN DAM H, MERTENS A and SINKELDAM J (1994) A coded checklist and ecological indicator values of freshwater diatoms from the Netherlands. Netherlands J. of Aquatic Ecol. 28 117-133.

VAN DER MOLEN JS (2000) Diatoms as Indicators of Water Quality in South African River Systems. Unpublished Ph.D. thesis, University of Port Elizabeth (now Nelson Mandela Metropolitan University). $130 \mathrm{pp}$.

WECKSTRÖM K (2006) Assessing recent eutrophication in coastal waters of the Gulf of Finland (Baltic Sea) using subfossil diatoms. J. Paleolimnol. 35 571-592.

WILSON SE, CUMMING BF and SMOL JP (1994) Diatom-salinity relationships in 111 lakes from the interior plateau of British Columbia, Canada: the development of diatom based model for paleosalinity reconstructions. J. Paleolimnol. 12 197-221. 